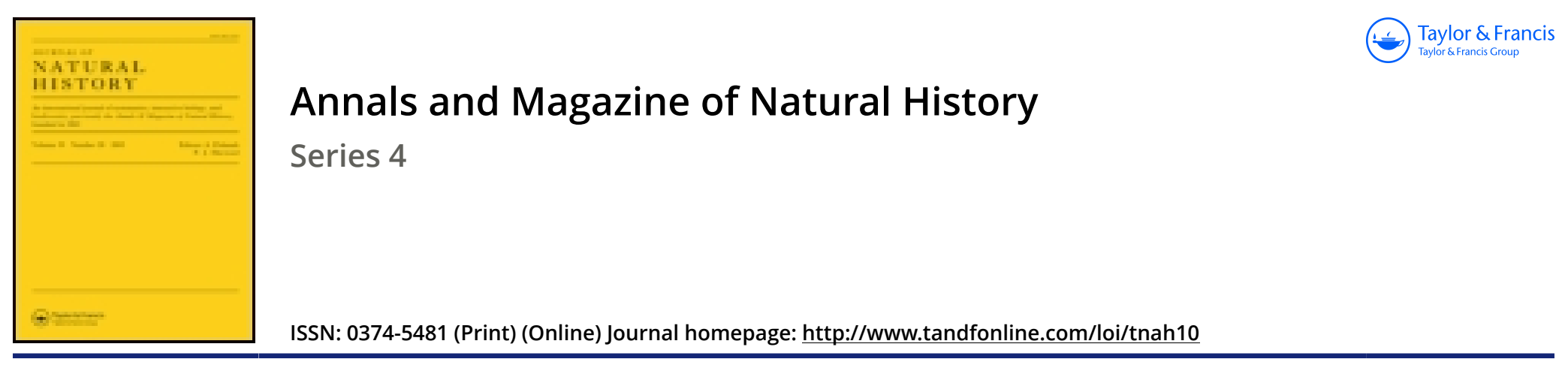

\title{
XXXVIII.-Revision of the Lepidopterous genus Cleis, with descriptions of the new species
}

\section{Arthur G. Butler F.L.S.}

To cite this article: Arthur G. Butler F.L.S. (1877) XXXVIII.-Revision of the Lepidopterous genus Cleis, with descriptions of the new species, Annals and Magazine of Natural History, 19:113, 393-396, DOI: $10.1080 / 00222937708682162$

To link to this article: http://dx.doi.org/10.1080/00222937708682162

\section{册Published online: 13 Oct 2009.}

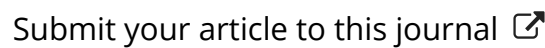

Џ Article views: 2 
crust; cc, central cylinder (compressed or oval form); $d$, fractured anterior extremity of the same; $e$, posterior extremity or tail more or less covered by the tuberculous layer; $f$, eminences of the tuberculous layer of a conical form attuched to the central cylinder, ? annelid-like; $g$, central longitudinal depression simulating dorsal vessel; $h$, commencement of a ?gemmiparous branch.

Fig. 3. The same: fragment of a central cylinder, broken (compressed form) to show its? segmented appearance, \&c. $a a$, remains of concretionary crust; $b b$, mould of tuberculous layer therein; $c c$, portions of tuberculous layer adherent to the cylinder; $d d$, central cylinder, showing the segmented appearance; $e$, central longitudinal depression simulating position of dorsal vessel; $f f$, lateral linear depressions simulating positions respectively of lateral vessels or segmental grooves; $g$, line of fracture; $h$, portion whose other side is represented in fig. 6 .

Fig. 4. The same: branched form. a $a a a$, concretionary crust; $b b b b$, casts and moulds respectively of tuberculous layer; $c c$, ? parent circular cylinder; $d d d d$, branches truncated respectively; $e$, ? gemmiparous projection or commencement of new branch on circular cylinder; $f$, form of the cells of that portion of the concretionary crust taken off $g$, where these cells (= mould of the tuberculous layer) are most regularly formed; $h h$, compressed cylinder.

This specimen looks as if the eircular branched cylinder $(o e)$ were in contact with the compressed form $(h h)$, all of which was enclosed within one and the same tuberculous layer, which was prolonged sheath-like upon the branches respectively.

Fig. 5. The sane: central cylinder (circular form) divested of the tuberculous layer to show the transverse reticular lineation. $a$, form of depressed reticular lineation with slightly raised or convex interstices (scale-like) where most regular.

Fig. 6. The same: the other side of that portion of fig. 3 marked " $h$," to show the form of the tuberculous layer when divested of the concretionary crust and still adherent to the central cylinder. $a$, central cylinder (compressed form); $b b$, tuberculous layer; $c c$, situation of sponge-spicules.

Fig. 7. The same: transverse section of a central cylinder (circular form), and its tuberculous layer divested of the concretionary crust, showing the relative position of the two former. a, central cylinder; $b$, tuberculous crust. Diagram.

Fig. 8. The same: transverse section of a central cylinder (compressed form), to show the same. $a$, central cylinder; $b b$, tuberculous layer; $c c$, incrustation of sponge-spicules \&c.

XXXVIII.-Revision of the Lepidopterous Genus Cleis, with Descriptions of the new Species. By ARTHur G. Butler, F.L.S. \&c.

THe genus Cleis is nearly allied to Callidula, Tyndaris, and Cleosiris. These four genera appear to me to be an aberrant group of the family Hypsidæ, and should be placed between the true Hypsidæ and the Melameridæ. 
The following is a list of the species hitherto described or represented by specimens in the collection of the British Museum.

1. Cleis dichroa.

Damias dichroa, Boisduval, Voy. de l'Astrolabe, i. Lep. p. 260. n. 3 (1832-35).

Mysol (Wallace).

Coll. B.M.

Originally described as coming from "Offack and Bourou." The chief peculiarities of this species consist in the orange band of primaries commencing at the base of the costa as a slender border, and the uniformly brown secondaries.

\section{Cleis arctato, n. sp.}

Allied to the preceding; purplish brown : primaries with a fulvous band, beginning very narrow at the middle of the costal margin and terminating on the outer margin, the lower half of which it occupies; its inner edge irregularly excised, its onter edge regular and oblique: secondaries with a narrow fulvous marginal band, which fades away before reaching the apex; fringe brown: underside clearer and brighter in colour; the band of primaries commencing at the base of costa, which it borders to the centre; its inner edge also regularly serrated; the band of secondaries also tapering off gradually, not obscured as on the upper surface: body below bright ochreous. Expanse of wings 1 inch 4 lines.

Ké Island (Wallace).

This is a very well-marked species.

Type, B.M.

\section{Cleis evander.}

Papilio evander, Cramer, Pap. Exot. iv. pl. ccexxxi. figs. F, G (1782).

Amboina and Ceram (Wallace).

Quite distinct from C. melaxanthe, with which Walker placed it.

\section{Cleis propinqua, n. sp.}

Allied to $C$. evander, but with the bands wider and deeper in colour, that of secondaries nearly twice as wide. Expanse of wings 1 inch 5 lines.

o, Ternate; + , Celebes (Wallace).

A local representative of the preceding species.

Type, B.M.

5. Cleis plagalis.

Cleis plagalis, Felder, Reise der Nov. Lep. iv. pl. cvii. fig. 22 (1874). Aru. 


\section{Cleis erycinoides.}

Cleis erycinoides, Felder, Reise der Nov. Lep. iv, pl. crii. fig. 23 (1874).

Ternate (Wallace).

B.M.

\section{Cleis fasciata, n. sp.}

․ Above deep purplish brown; primaries crossed beyond the cell by a rather narrow oblique orange band, from the subcostal nervure to just below the second median branch, both margins of this band irregularly serrated; secondaries crossed by a slightly broader discal band, its inner edge sinuated between the nervures to the radial vein, above which the band is slightly broader to the second subcostal branch, whence it tapers to near the costa; palpi orange, spotted with black : wings below with the band of primaries wider towards the costa than on the upper surface; a continuous submarginal lilac line; pectus and legs orange, venter with a central longitudinal pale ochreous stripe. Expanse of wings 1 inch 6 lines.

Ternate (Wallace).

Type, B.M.

Readily distinguished from the preceding by the position and width of the orange bands, that of the primaries crossing the wing just beyond the discoidal cell, that of the secondaries having the brown border beyond it of double the width.

\section{Cleis aruana, n. sp.}

Above chocolate-brown; primaries crossed immediately beyond the cell by a rather broad ochreous band from the subcostal to the first median branch; secondaries crossed from the inner margin to the first subcostal branch by a broad irregular terminally tapering ochreous patch, its central area alnost circular: wings below with the ochreous areas paler and clearer; the basal half of costa in primaries orange; a dot in each of the discoidal cells and a squamose subapical spot in primaries lilac; body below ochreous. Expanse of wings 1 inch 6 lines.

Aru (Wallace).

Type, B.M.

In coloration above this is most like $C$. versicolor; in the position of the band of primaries it agrees best with $C$. fasciata.

\section{Cleis versicolor.}

Cleis versicolor, Felder, Reise der Nov. Lep. iv. pl. cvii. fig. 24 (1874).

Dorey (Wallace). $\quad$ B.M.

In the coloration of the under surface this species some- 
what resembles Callidula; in structure, however, it agrees with Cleis. I believe the Agonis lyconoides of Felder to be a slightly aberrant form of Cleosiris, to which genus the following species are referable-C. erycinoides (of Walker), $C$. anchora, C. Felderi, and C. catamita.

\section{Cleis posticalis.}

Cleis posticalis, Guérin, Voy. Duperrey, Atlas, Ins. pl. 18. f. 5.

Damias melaxanthe, Boisduval, Voy. de ''Astrolabe, p. 260. n. 2 (1832-5).

Duke-of-York Island (Rev. G. Brown).

B.M.

Our example was recently presented to the collection by $\mathrm{F}$. Du Cane Godman, Esq. The allied genus Callidula contains four species, C. petavius, C. abisara, C. sakuni, and C.jucunda; the genus Tyndaris, $T$. erycinata (the male of which is figured by Felder as that sex of his $T$. latifica) and $T$. laetifica.

The Damias elegans of Boisdural is probably congeneric with the Nyctemera subaspersa of Walker, for which, therefore, I shall provisionally retain the name. N. subaspersa, although coloured somewhat like Secusio annulata, has long, slender, filiform antennæ, and is more nearly allied to Cleis.

\section{XXXIX.-On the Elateridæ of New Zealand. By D. Sharp.}

IN this paper I have put together descriptions of all the beetles belonging to the family Elateridx I have been able to procure from New Zealand, and have indicated their structural characters in a manner which, al though very imperfect, will, I believe, allow the names and affinities of most of the species to be determined without much difficulty.

I have included under the Elateridæ four or five species of Eucnemidæ; for though several able entomologists consider the Eucnemidæ to be a distinct family, I am unable myself to consider them such so long as the present extension is granted to the Elateridæ. The Eucnemida, in fact, possess no point of real distinction from the Elateridæ: the form of the head (which is usually relied on to separate the two families) is not a sufficient character; for it undergoes various modifications in both the Eucnemidæ and Elateridæ, and in some species of Eucnemidæ its structure is more different from that of the typical members of the family than it is from that of the Elaterida. Taking the term Elateridæ, then, in this wide sense, I have been able to distinguish about sixty-two 